\title{
Tindak Pidana Korporasi Bagi Perusahaan Yang Terlibat Dalam Pencucian Uang Hasil Penjualan Narkotika
}

\section{Corporate Crime Following Companies Involved In Money Laundering of Drug Sales Results}

\author{
Aris Wibowo* , Triono Eddy \& Alpi Sahari \\ Program Magister Ilmu Hukum, Universitas Muhammadiyah Sumatera Utara, Indonesia.
}

Diterima: Juni 2020; Disetujui: Agustus 2020; Dipublish: Agustus 2020

*Email: wibowoaris873@gmail.com

\begin{abstract}
Abstrak
Badan Nasional dibentuk untuk lebih mengintensifkan pemberantasan tindak pidana narkotika merupakan salah satu dari extra ordinary crime. Tindak pidana narkotika ternyata juga memberikan satu fakta bahwa untuk menjejakkan hasil penjualan narkotika maka uangnya dialihkan, diatas namakan, atau dibentuk sebuah korporasi lain sebagai kamuflase agar tidak terlacak oleh aparat kepolisian. Pada awalnya korporasi tidak dapat dipidana dengan berbagai alasan, namun belakangan korporasi dapat dipidana. Penelitian ini bertujuan untuk menganalisis kebijakan kriminal tindak pidana korporasi bagi rerusahaan yang terlibat dalam pencucian uang hasil penjualan narkotika serta hambatan dan solusi yang dilakukan oleh BNN propinsi Sumatera Utara dalam penanaganan kasus tindak pidana korporasi bagi perusahaan yang terlibat dalam pencucian uang hasil penjualan narkotika. Hasil dari pada penelitian ini menunjukkan kebijakan kriminal tindak pidana korporasi bagi perusahaan yang terlibat dalam pencucian uang hasil penjualan narkotika dengan adanya undang-undang pencucian uang yang sebelumnya tidak diatur secara tegas, antara lain bahwa subjek tindak pidana bagi korporasi bagi perusahaan. Hambatan yang yang dihadapi BNN Sumatera Utara adalah sulitnya mendapatkan informasi terkait dengan penelusuran mengenai objek hasil tindak pidana pencucian uang. Hambatan lain terkaiat penyitaan aset tersangka yang harus bekerjasama dengan pihak bank, sarana dan prasarana yang minim serta rendahnya profesionalitas penegak hukum.
\end{abstract}

Kata Kunci: Tindak Pidana, Korporasi, Norkotika.

\begin{abstract}
The National Agency was formed to further intensify the eradication of narcotics crime is one of the extra ordinary crimes. It turns out that narcotics crime also provides a fact that to track the proceeds of the sale of narcotics, the money is diverted, on behalf of, or formed by another corporation as a camouflage so that it is not tracked by the police. Initially, corporations cannot be convicted for various reasons, but later corporations can be convicted. This study aims to analyze the criminal policy of corporate criminal acts for companies involved in money laundering from the sale of narcotics as well as obstacles and solutions carried out by BNN of North Sumatra province in the handling of corporate criminal cases for companies involved in money laundering from narcotics sales. The results of this study indicate the criminal policy of corporate criminal acts for companies involved in money laundering from the sale of narcotics with the existence of money laundering laws that were not previously explicitly regulated, including that the subject of criminal acts for corporations for companies. The obstacle faced by the North Sumatra National Narcotics Agency is the difficulty of obtaining information related to searches regarding objects resulting from money laundering crimes. Another obstacle is the confiscation of the assets of the suspect who must cooperate with the bank, the lack of facilities and infrastructure and the low professionalism of law enforcement.
\end{abstract}

Keywords: Criminal Acts, Corporations, Narcotics.

How to Cite: Wibowo, A., Eddy, T. \& Sahari, A. (2020). Tindak Pidana Korporasi Bagi Perusahaan Yang Terlibat Dalam Pencucian Uang Hasil Penjualan Narkotika. Journal of Education, Humaniora and Social Sciences (JEHSS). 3 (1): $52-$ 60 . 


\section{PENDAHULUAN}

Kejahatan sekarang menunjukkan bahwa kemajuan ekonomi menimbulkan kejahatan bentuk baru yang tidak kurang bahaya dan besarnya korban yang diakibatkannya. Indonesia dewasa ini sudah dilanda kriminalitas kontemporer yang cukup mengancam lingkungan hidup, sumber energi, dan pola-pola kejahatan bentuk baru, seperti kejahatan bank, kejahatan komputer, penipuan terhadap komputer, penipuan terhadap konsumen berupa barang-barang produksi kualitas rendah yang keramas indah dan dijajakan lewat advertensi secara besar-besaran, dan kejahatan korporasi yang beroprasi lewat penetrasi dan penyamaran (Tambunan, 2016).

Korporasi sudah dikenal dalam dunia bisnis sejak beberapa abad yang lalu. Pada awalnya, korporasi hanya merupakan suatu wadah kerjasama dari beberapa orang yang mempunyai modal, untuk mendapatkan keuntungan bersama, dan belum seekslusif seperti korporasi dewasa ini. Munculnya revolusi industri telah mendorong semaki berkembangnya korporasi sebagai badan hukum dan badan ekonomi. Barangkali VOC yang didirikan oleh Belanda pada tahun 1602 dapat dipandang sebagai perintis korporasi (bisnis) modern yang dibangun dengan modal saham yang tetap (Prasetyo, Ma'ruf, Mashdurohatun).

Korporasi banyak memberikan kontribusi perkembangan suatu negara, terutama dalam bidang ekonomi, misalnya pemasukan negara dalam bentuk pajak maupun devisa, sehingga dampak korporasi tampak sangat positif. Namun di sisi lain, korporasi juga tak jarang menciptakan dampak negatif, seperti pencemaran, pengurasan sumber daya alam, persaingan secara curang, manipulasi pajak, eksploitasi terhadap buruh, menghasilkan produk-produk yang membahayakan pemakainya, serta penipuan terhadap konsumen (Setiyono, 2005).

Kasus Fredi Budiman layak menjadi satu contoh kasus tentang bagaimana hasil penjualan narkoba kemudian dilakukan pencucian uang. Badan Narkotika Nasional menyita aset hasil tindak pidana pencucian uang yang dilakukan jaringan terpidana mati Freddy Budiman. Tersangka Freddy Budiman dan para koleganya menggunakan modus dengan membangun perusahaan fiktif yang melakukan ekspedisi ekspor-impor. Freddy Budiman tersangka ini memiliki enam perusahaan fiktif. Transaksi tersebut dilakukan dalam 2014 hingga 2016. Selama itu perusahaan tidak pernah sama sekali melakukan ekspedisi ekspor-impor. Selama dua tahun, perusahaan fiktif itu telah mengeluarkan sekurangnya 2.136 invoice dengan total transaksi Rp 6,4 triliun. Pengiriman itu dilakukan dengan menggunakan sejumlah rekening bank. Berdasarkan pemaparan latar belakang diatas maka penulis tertarik untuk melakukan penelitaian dengan judul "tindak pidana korporasi bagi perusahaan yang terlibat dalam pencucian uang dari hasil penjualan narkotika".

\section{METODE PENELITIAN}

Metode yang dimunakan dalam penelitian ini ialah penelitian hukum normatif dengan dua pendekatan, yaitu dengan pendekatan undang-undang (statute approach), yaitu pendekatan penelitian terhadap produk-produk hukum, pendekatan konseptual (Conceptual approach) yaitu pendekatan terhadap konsep-konsep hukum seperti lembaga hukum, fungsi hukum dan sumber hukum. Adapun penelitian ini bersifat deskriftif analisis yang menggambarkan objek, menerangkan dan menjelaskan sebuah peristiwa dengan maksud untuk mengetahui keadaan objek yang diteliti dengan memberikan data yang seteliti mungkin tentang manusia, keadaan atau gejala-gejala lain (Soekamto, 2014).

\section{HASIL DAN PEMBAHASAN \\ Kebijakan Kriminal Tindak Pidana Korporasi Bagi Perusahaan yang Terlibat dalam Pencucian Uang Hasil Penjualan Narkotika}

Tindak pidana narkotika tidak lagi dilakukan secara perseorangan, melainkan melibatkan banyak orang yang secara bersama-sama, bahkan merupakan satu sindikat yang terorganisasi dengan jaringan yang luas yang bekerja secara rapi dan sangat rahasia baik di tingkat nasional maupun maupun internasional, menggunakan modus operandi yang tinggi, teknologi canggih, sangat sulit membuktikan perbuatan pidana dan pertanggungjawaban pelaku. Penjatuhan 
hukuman yang berat ternyata tidak membuat jera bagi para pelaku terbukti bahwa peredaran gelap narkotika tetap meningkat dan dikendalikan pelaku walaupun berada dalam lembaga pemasyarakatan atau pun rumah tahan karena masih memiliki banyak uang. Harta kekayaan adalah titik terlemah dari rantai kejahatan sehingga penghancuran jaringan keuangan merupakan upaya memiskinkan para pelaku agar peredaran gelap narkotika dapat ditekan adanya paradigma baru dalam melawan kejahatan yaitu follow the money, penelusuran dalam rangka mengetahui harta kekayaan untuk disita dan dirampas untuk negara (Sundari, 2014).

Kejahatan atau kegiatan ilegal yang dilakukan secara terus menerus oleh perorangan atau kelompok penjahat menghasilkan uang yang tidak sedikit. Uang hasil kejahatan diibaratkan seperti darah yang memberi kehidupan dalam tubuh makhluk hidup, karena uang tersebut dialirkan kembali untuk bisnis kejahatan, sehingga bisnis kejahatan dapat terus berjalan selama dana hasil kejahatan tersebut ada. Prinsip ekonomi tidak dapat dihindari dari setiap tatanan kehidupan manusia, baik dalam berbuat jahat ataupun dalam kehidupan normal (baik). Eksistensi pencucian uang dapat dibuktikan dengan kenyataan bahwa kejahatan (besar) tetap hidup. Kejahatan dan tindak pidana pencucian uang bagaikan dua sisi mata uang, selalu berdampingan, saling membutuhkan dan tidak mungkin dilepaskan satu sama lainnya. Pencucian uang mungkin sama tuanya dengan eksistensi uang itu sendiri (Muller, Kalin, John, 2007). Uang yang dicuci adalah uang hasil bermacam-macam kejahatan. pencucian uang adalah suatu kejahatan (undelying crime) yang berasal dari tindak pidana lainnya (predicate crime) sebagai asal dana. Menurut Prof. Barda Nawawi Arief, predicate crime atau predicate offence adalah detik-detik yang menghasilkan criminal proceeds atau hasil kejahatan yang kemudian dicuci (Arief, 2003).

Ada beberapa pertimbangan suatu tindak pidana dikaitkan dengan undang-undang anti pencucian uang. Pertama, kejahatan asal tersebut sangat berbahaya bagi kemanusiaan seperti tindak pidana terorisme. Kedua, kerugian yang diakibatkan oleh kejahatan asal sangat besar seperti penipuan dan korupsi. Ketiga kejahatan itu berdampak sangat merusak seperti peredaran dan penyelundupan narkoba. Reuter and Truman berdasarkan hasil penelitiannya memasukkan lima macam kejahatan asal (predicate offences) dari pencucian uang, yaitu drug distribution, other bleucollar crime, white-collar crime, bribery and corruption, and terrorism. Alasan Reuter dan Truman memilih kejahatan-kejahatan ini sebagai kejahatan asal pencucian uang adalah adamya homogenitas dari masing-masing kejahatan tersebut yaitu dampaknya yang sangat merusak terhadap masyarakat (Levi \& Reuter, 2006).

Menyangkut penetuan tindak pidana asal dalam tindak pidana pencucian uang terhadap tindak pidana narkotika dapat dilihat dari karakteristik sebagai berikut (Puroko, 2001). Pola tindak pidana pencucian uang dari harta kekayaan hasil tindak pidana narkotika. Modus kejahatan penyalahgunaan narkotika dengan memanfaatkan lembaga keuangan untuk melakukan tindakan penyembunyian dan penyamaran harta kekayaan hasil tindak pidana narkotika dari waktu ke waktu semakin kompleks dengan menggunakan teknologi dan rekayasa keuangan yang cukup complicated. Secara sederhana, kegiatan penyamaran dan penyembunyian harta kekayaan hasil tindak pidana narkotika ini pada dasarnya dapat dikelompokkan pada tiga pola kegiatan yang biasanya dilakukan oleh jaringan sindikat narkotika, yakni: placement, layering dan integration.

Hubungan tindak pidana pencucian uang dengan tindak pidana asal tindak pidana penyalahgunaan narkotika dapat dilihat pada Pasal 2 ayat (1) huruf a bahwa hasil tindak pidana adalah harta kekayaan yang diperoleh dari tindak pidana yang dilakukan di wilayah Indonesia atau di luar wilayah Negara Republik Indonesia dan tindak pidana tersebut juga merupakan tindak pidana pencucian uang kalau tidak ada kejahatan yang menghasilkan uang/harta kekayaan yakni harta kekayaan hasil tindak pidana narkotika. Penerapan ketentuan anti pencucian uang di dalam undang-undang bertujuan tidak saja menangkap pelaku organized crime penyalahgunaan narkotika tetapi juga menelusuri hasil kejahatan dan kemudian merampasnya.

Kejahatan narkotika dengan maksud menyembunyikan dan menyamarkan harta kekayaan hasil kejahatan melalui lembaga keuangan bagi pelaku dipandang sebagai suatu aktifitas sangat menguntungkan serta hanya melibatkan orang tertentu dan transaksi tertentu yang biasanya tidak meninggalkan bukti fisik serta tidak menimbulkan korban individu. Menerima uang hasil narkotika baik tunai maupun melalui transfer dan digunakan untuk membeli harta berupa barang bergerak, 
barang tidak bergerak, surat berharga, saham perusahaan, membayar premi asuransi, Menyembunyikan dan menyamarkan asal usul harta milik tersangka narkotika dengan cara menempatkan uang milik tersangka narkotika disafe deposit box salah satu bank menggunakan namanya sendiri (Sundari, 2014). Pemidanaan terhadap korporasi, sekalipun sering dikaitkan dengan masalah finansial, namun sebenarnya mengandung tujuan yang lebih jauh. Hal ini terungkap dari pandangan Friedmann bahwa : "The main effect and usefulness of a criminalconviction improsed upon a corporation cannot be seen either in any personal injury or, in most cases, in the financial detriment, but in the public opprobrium ans stigma that attaches to a criminal conviction"(Friedmann, 2010).

Kejahatan ini semakin besar dan meningkat mengingat tindak pidana pencucian uang ini dilakukan oleh korporasi. Kejahatan korporasi adalah kejahatan yang dilakukan oleh kolektif atau kumpulan individu dengan bidang (pekerjaan) yang berbeda. Pada intinya, untuk dapat disebut sebagai kejahatan korporasi, jika pejabat atau pengurus korporasi melakukan pelanggaran hukum untuk kepentingan korporasi (Marshall \& Peter, 1980). Korporasi dalam hukum pidana umum, belum dimasukkan sebagai subyek hukum. Pandangan tentang subyek hukum pidana di bidang hukum pidana umum yang hanya terbatas pada orang pribadi, tidak dapat dilepaskan dengan sejarah pembentukan WvS Nederland tahun 1881, dimana pada dasarnya hanya manusia dapat dipandang sebagai subyek hukum pidana. Hal ini dapat diketahui dari, Memory van Toelichting Pasal 51 WvS Nederland (Pasal 59 KUHP): suatu strafbaarfeit hanya dapat diwujudkan oleh manusia dan fiksi tentang badan hukum tidak berlaku dalam bidang hukum pidana, Uraian delik dalam banyak pasal WvS selalu dimulai dengan "Barang Siapa" dan sering disyaratkan adanya berbagai faktor manusia, seperti sengaja dan lalai, faktor mana hanya dapat dimiliki oleh manusia, Sistem pidana terdiri dari pidana kekayaan dan pidana badan hanyalah dapat dikenakan terhadap manusia, Hukum acara pidana tidak mengandung ketentuan tatacara terhadap korporasi (Abidin, 1983).

Sejalan dengan perkembangan dunia internasional (salah satunya adalah International Meeting of Experts on the Use of Criminal Sanction in 'The Protectionof Enviropment, Internationally, Domestically and Regionally, Portland, Oregon,USA, 19-23 March 1994) menempatkan korporasi sebagai subjek tindak pidana. Dalam pertemuan dirumuskan mengenai pertanggungjawaban korporasi (Legal entityliability) yang ditentukan dengan delik-delik yang dirumuskan dalam generic crimes dan specific crimes dapat dipertanggungjawabkan terhadap seseorang individu maupun korporasi, dengan ketentuan bahwa delik itu dilakukan dalam rangka pelaksanaan kegiatan organisiasi (korporasi) itu, Pertama, pertanggungjawaban korporasi terjadi apabila ada kesalahan manajemen dari koorporasi itu dan telah terjadi generic crimes; atau, ada pelanggaran peraturan atau ketentuan undang-undang oleh korporasi itu. Kedua, pertangungjawaban korporasi dikenakan juga pada pertanggungjawaban perseorangan dan manajer, petugas, agen, karyawan atau pelayan dan korporasi itu. Ketiga, Pertanggungjawaban korporasi diterapkan tanpa memperhatikan apakah orang atau individu yang melakukan perbuatan atas nama korporasi itu telah diidentifikasikan, telah dituntut atau telah dipidana atau tidak dan semua sanksi, kecuali sanksi pidana penjara, dapat dikenakan kepada korporasi (Arief, 1995).

Pengakuan korporasi sebagai subjek hukum yang dapat dipertanggungjawabkan dalam tindak pidana pencucian uang ditegaskan dalam Undang-Undang Nomor 8 Tahun 2010. Pasal 1 angka 9 Undang-Undang Nomor 8 Tahun 2010 menyebutkan bahwa "setiap orang adalah orang perseorangan atau korporasi". Selanjutnya Pasal 1 angka 10 menyebutkan bahwa korporasi adalah kumpulan orang dan /atau kekayaan yang terorganisasi baik merupakan badan hokum maupun bukan badan hukum. Dengan demikian menurut Undang-Undang Nomor 8 Tahun 2010 subjek tindak pidana pencucian uang tidak hanya "orang perseorangan" tetapi juga korporasi. Pertanggungjawaban pidana korporasi diatur dalam ketentuan Pasal 6 Undang-Undang Nomor 8 Tahun 2010. Pasal 6 ayat (1) menentukan "Dalam hal tindak pidana Pencucian Uang sebagaimana dimaksud dalam Pasal 3, Pasal 4, dan Pasal 5 dilakukan oleh Korporasi, pidana dijatuhkan terhadap Korporasi dan/atau Personil Pengendali Korporasi." Selanjutnya di dalam ayat (2) ditentukan, Pidana dijatuhkan terhadap Korporasi apabila tindak pidana Pencucian Uang, dilakukan atau diperintahkan oleh Personil Pengendali Korporasi, dilakukan dalam rangka pemenuhan maksud 
dan tujuan Korporasi, dilakukan sesuai dengan tugas dan fungsi pelaku atau pemberi perintah, dilakukan dengan maksud memberikan manfaat bagi korporasi.

Personil Pengendali Korporasi sebagaimana yang diatur dalam pasal 1 angka 14 Undangundang Nomor 8 Tahun 2010. Subjek hukum menurut Sudikno Mertokusumo adalah segala sesuatu yang dapat memperoleh hak dan kewajiban dari hukum. Yang dapat memperoleh hak dan kewajiban dari hukum adalah manusia. Jadi manusia oleh hukum diakui sebagai penyandang hak dan kewajiban, sebagai subjek hukum atau sebagai orang (Mertokusumo, 1999). Korporasi dapat dipidana sebagaimana yang diatur dalam Undang-undang Nomor 8 Tahun 2010.

Dalam The National Money Laundering Strategy for 2000 (strategi pencucian uang nasional), yang diterbitkan oleh Pemerintah Amerika Serikat pada Maret 2000 dikemukakan bahwa pencucian uang wajib diberantas karena tiga alasan, yaitu, Pencucian uang adalah sarana penting bagi kejahatan yang menghasilkan uang, baik kejahatan narkoba, kecurangan, maupun bentukbentuk kejahatan lainnya, Pencucian uang membantu para pejabat negara asing yang melakukan korupsi untuk dapat menyembunyikan kekayaan masyarakat yang diperolehnya secara tidak jujur, sering kali kekayaan itu berupa kekayaan yang diberikan oleh Pemerintah Amerika Serikat untuk keperluan meningkatkan kehidupan warga negara, Pemberantasan pencucian uang membantu Amerika Serikat untuk mepertahankan integritas dari sistem keuangan dan lembaga-lembaga terhadap pengaruh buruk dari uang hasil kejahatan.

Sehubungan dengan penggunaan hukum pidana sebagai sarana pengayoman masyarakat terhadap tindak pidana korporasi, John C. Coffe mengatakan bahwa, Hukum pidana dipandang mampu melaksanakan peranan edukatif dalam mendefinisikan atau menetapkan dan memperkuat batas-batas perbuatan yang dapat diterima (acceptable conduct), Hukum pidana bergerak dengan langkah lebih cepat daripada perdata, dengan pidana restitusi lebih cepat memperoleh bagi korban, Peradilan perdata terhalang untuk mengenakan sanksi pidana, Penuntutan bersama (korporasi dan agennya) memerlukan suatu forum pidana, apabila ancaman pengurangan digunakan untuk mencegah individu. Dari sudut penegakan hukum, peradilan bersama itu cukup beralasan karena lebih murah dibandingkan dengan penuntutan terpisah, dan karena mereka mengizinkan penuntut umum mengikuti kasus itu dalam cara yang terpadu (John, 1998).

Apabila dicermati secara seksama rumusan pertanggungjawaban korporasi dalam ketentuan Pasal 6 ayat (2) Undang-Undang Nomor 8 Tahun 2010, rumusan pertanggungjawaban pidana korporasi dimaksud merupakan penyempurnaan pertanggungjawaban korporasi dalam Undang-Undang Nomor 25 Tahun 2003 yang masih menganut doktrin pertanggungjawaban "vicarious liability" dalam arti terbatas (yaitu hanya didasarkan pada "the delegation principle"). Berdasarkan keterangan yang diperoleh melalui informan di BNN Sumatera Utara didapat keterangan bahwa BNN Sumatera Utara dalam menjalankan tugas untuk membongkar praktik tindak pidana pencucian uang hasil kejahatan penjualan narkotika, telah menjalankan tugas dan kewajibannya secara proporsional dan profesional. Tugas BNN untuk melacak keberadaan korporasi yang diduga melakukan praktik pencucian uang hasil penjualan narkotika, untuk menjawab tugas negara yang diemban.

\section{Hambatan dan Solusi yang Dilakukan oleh BNN Provinsi Sumatera Utara dalam Penanganan Kasus Tindak Pidana Korporasi Bagi Perusahaan Yang Terlibat Dalam Pencucian Uang Hasil Penjualan Narkotika}

Dalam upaya pemberantasan kejahatan narkotika aparat penegak hukum tidak hanya menerapkan Undang-Undang No. 35 tahun 2009 tentang Narkotika, namun juga menerapkan Undang-Undang No. 8 Tahun 2010 Tentang Pencegahan dan Pemberantasan Tindak Pidana Pencucian Uang. Penggunaan Undang-Undang No. 8 Tahun 2010 Tentang Pencegahan dan Pemberantasan Tindak Pidana Pencucian Uang untuk memberantas tindak pidana narkotika disebabkan karena berbagai modus kejahatan narkotika terus dilakukan oleh para pelaku kejahatan untuk kelancaran bisnis haramnya. Bahkan hasil kejahatan narkotika yang diperoleh para pelaku, dialihkan dalam bentuk kegiatan lain dengan maksud mengaburkan kejahatan narkotika yang dilakukan oleh para pelaku. 
Kejahatan peredaran gelap narkotika sejak lama diyakini memiliki kaitan erat dengan proses pencucian uang. Sejarah perkembangan tipologi pencucian uang menunjukkan bahwa perdagangan narkotika merupakan sumber yang paling dominan dan kejahatan asal (predicate crime) yang utama yang melahirkan kejahatan pencucian uang. Organized crime (kejahatan terorganisir) selalu menggunakan metode pencucian uang ini untuk menyembunyikan, menyamarkan atau mengaburkan hasil bisnis haram itu agar nampak seolah-olah merupakan hasil dari kegiatan yang sah (Nugroho, 2017; Guraba, dkk., 2018; Arifin, dkk., 2019). Selanjutnya, uang hasil jual beli narkotika yang telah dicuci itu digunakan lagi untuk melakukan kejahatan serupa atau mengembangkan kejahatan-kejahatan baru. Sejarah mencatat pula bahwa kelahiran rezim hukum internasional yang memerangi kejahatan pencucian uang dimulai pada saat masyarakat internasional merasa frustrasi dengan upaya memberantas kejahatan perdagangan gelap narkotika (Husein, 2014).

Pada saat itu, rezim anti pencucian uang dianggap sebagai paradigma baru dalam memberantas kejahatan yang tidak lagi difokuskan pada upaya menangkap pelakunya, melainkan lebih diarahkan pada penyitaan dan perampasan harta kekayaan yang dihasilkan (Khairul, dkk., 2011; Nasution, 2017). Logika dari memfokuskan pada hasil kejahatannya adalah bahwa motivasi pelaku kejahatan akan menjadi hilang apabila pelaku dihalang-halangi untuk menikmati hasil kejahatannya. Tentunya dengan adanya korelasi yang erat ini antara kejahatan peredaran gelap narkotika sebagai predicate crime (kejahatan asal) dan kejahatan pencucian uang sebagai derivative-nya, maka sangat jelas bahwa keberhasilan perang melawan kejahatan peredaran gelap narkotika di suatu negara sangat ditentukan oleh efektivitas rezim anti pencucian uang di negara itu (Husein, 2014).

Tindak pidana narkotika terus mengalami peningkatan setiap tahunnya hal ini mendorong perubahan Undang-Undang Nomor 22 Tahun 1997 tentang Narkotika dan berhasil ditetapkannya Undang-Undang Nomor 35 Tahun 2009 tentang Narkotika. Dalam undang-undnag ini menyebutkan upaya pencegahan dan pemberantasan penyalahgunaan serta peredaran gelap narkotika dan prekursor narkotika dengan membentuk Badan Narkotika Nasional atau biasa disingkat dengan BNN sebagaimana tercantum dalam Pasal 64 ayat (1), (Nurdin, 2013). BNN memiliki kewenangan untuk melakukan penyidikan terhadap perkara penyalahgunaan, dan peredaran gelap narkotika sebagaimana diatur dalam Undang-Undang Nomor 35 Tahun 2009 tentang Narkotika karena merupakan lex specialis dari hukum pidana formil Indonesia yakni KUHAP (Wiretno. 2014).

Akan tetapi dalam proses pelaksanaan penyidikan pada kasus tindak pidana narkotika, penyidik menemukan ada perkembangan kasus tindak pidana lain seperti tindak pidana pencucian uang atau money laundering yang diatur dalam Undang-Undang Nomor 8 Tahun 2010 tentang Pencegahan dan Pemberantasan Tindak Pidana Pencucian Uang. Tindak pidana pencucian uang tidak berdiri sendiri karena harta kekayaan yang ditempatkan, ditransfer, atau dialihkan dengan cara integrasi itu diperoleh dari tindak pidana, berarti sudah ada tindak pidana lain yang mendahuluinya (predicate crime). Macam-macam predicate crime tercantum dalam Pasal 2 UndangUndang No 8 Tahun 2010 tentang Pencegahan dan Pemberantasan Tindak Pidana Pencucian Uang termasuk salah satunya tindak pidana narkotika yang disebutkan pada Pasal 2 huruf (c). Banyaknya keuntungan yang diperoleh dari transaksi narkotika, memunculkan adanya pemikiran dari pelaku untuk menyembunyikan atau menyamarkan uang hasil transaksi narkotika tersebut. Hal inilah yang mengindikasikan bahwa tindak pidana pencucian uang mempunyai hubungan yang sangat erat dengan tindak pidana narkotika sebagai tindak pidana asal (predicate crime) (Wiretno, 2014).

BNN sendiri mempunyai kewenangan dalam melakukan penyidikan terhadap tindak pidana money laundering sebagaimana tercantum dalam Pasal 74 Undang-Undang Nomor 8 Tahun 2010 tentang Pencegahan dan Pemberantasan Tindak Pidana Pencucian Uang yang menyebutkan bahwa penyidikan tindak pidana Pencucian Uang dilakukan oleh penyidik tindak pidana asal sesuai dengan ketentuan hukum acara dan ketentuan peraturan perundang-undangan, kecuali ditentukan lain menurut Undang-Undang ini. Dalam melaksanakan tugas, peran, fungsi serta wewenangnya, BNN tentu saja mengalami banyak hambatan atau kendala, sehingga menyulitkan untuk mengungkaplan tindak pidana pencucian uang. 
Berdasarkan keterangan yang dihimpun melalui informan, ditemukan bahwa hambatan yang paling besar adalah sulitnya mendapatkan informasi terkait dengan penelusuran mengenai harta yang menjadi objek hasil tindak pidana pencucian uang. Penanganan kasus TPPU, dimana dalam hal ini BNN Sumatera Utara bekerja sama dengan PPATK dalam melakukan pengungkapan atas kejahatan Narkotika, maka strategi Badan Narkotika Nasional Sumatera Utara adalah:

1. Mengumpulkan keseluruhan Data dari PPATK, Penanganan kasus Tindak Pidana Pencucian uang BNND bekerja sama dengan PPATK dalam mengungkap keseluruhan aset yang dimiliki oleh Bandar Narkotika. Penyidik BNND hal pertama yang dilakukan meminta keseluruhan data yang dimiliki ke PPATK, lalu mengumpulkan keseluruhan Data tersebut untuk dapat dipastikan apakah ia dapat dikatakan melakukan TPPU. Hal itu dilakukan juga dilihat dari TPA (tindak pidana asalnya) seperti seseorang tersebut berasal dari kasus Narkotika. Bahwa koordinasi antara PPATK dengan BNN Provinsi sangatlah penting. Kewenangan BNN sebagaimana disebutkan dalam Pasal 80 huruf (d) Undang-Undang No. 35 Tahun 2009 tentang Narkotika yakni memiliki kewenangan untuk mendapatkan informasi dari Pusat Pelaporan dan Analisis Transaksi Keuangan yang terkait dengan penyalahgunaan dan peredaran gelap narkotika dan prekursor narkotika.

2. Melakukan Pelacakan atas Rekening, Kendala utama yang dihadapi oleh BNN Sumatera Utara sendiri ialah lambannya koordinasi yang dilakukan dengan BNN RI. Seperti diketahui sebelumnya bahwa untuk mendapatkan data mutasi bank dan melakukan pemblokiran rekening bank, BNN Daerah harus terlebih dahulu mengajukan surat permohonan permintaan data mutasi bank dan surat permohonan permintaan pemblokiran atas nama tersangka beserta dengan Laporan Pengajuan Perkara yang berisi resume berkas perkara kepada BNN RI.

3. Penyitaan Aset Penyidikan tidak hanya dilakukan dengan penyidikan secara teknologi, tapi juga melakukan penyidikan secara konvensional. Penyidikan konvensional dapat berupa informasi-informasi dari masyarakat yang mana penyidik melakukan on the spot dan memastikan dengan jalan bertanya pada masyarakat sekitar yang dianggap mengetahui tentang kebenaran asal-usul harta kekayaan milik tersangka.

Batas minimal penyitaan pada kasus TPPU berbeda dengan kasus Korupsi, yang apabila aset yang dimiliki oleh para pengedar hanya sedikit, maka akan dimasukkan kedalam Tindak Pidana Narkotika, itu disebabkan karena kurangnya anggaran yang dimilki oleh BNND. Memacu pada indikasi kasus tersebut para Bandar yang mempunyai aset besar yang tersimpan melalui rekening keluarga bahkan orang lain yang diakui mempunyai kerjasama dengan tersangka, akan dilakukan penyidikan oleh Badan Narkotika Nasional. Penyitaan aset yang dilakukan oleh pihak penyidik tersebut adalah aset yang dimiliki oleh Bandar Narkotika tersebut. Dalam penyitaan asetdengan kasus Narkotika, BNND hanya bekerjasama hanya dengan pihak BNND saja tidak melibatkan pihak instansi lain. Penyitaan aset yang sering didapatkan oleh BNND adalah berupa rumah, mobil, tanah, perhiasaan,dan lain-lain (Surbekti : 2016).

Keterangan melalui informan di BNN Provinsi Sumatera Utara menyebutkan kendala lainnya adalah ketersediaan sarana dan prasarana yang kurang memadai. Harus diakui bahwa penyidikan terhadap kasus pencucian uang hasil tindak pidana narkotika bukanlah sesuatu yang mudah untuk dilakukan. Hal ini dikarenakan banyaknya tahapan-tahapan yang harus dilakukan oleh penyidik tersebut. Misalnya diperlukan digital forensik untuk melacak keberadaan uang hasil pencucian uang. Tanpa adanya sarana atau fasilitas maka tidak akan mungkin penegakan hukum akan berlangsung dengan lancar. Sarana atau fasilitas tersebut antara lain mencakup tenaga manusia yang berpendidikan dan terampil, organisasi yang baik, peralatan yang memadai, keuangan yang cukup dan lain sebagainya (Soekanto: 2014).

Informan dari BNN Provinsi Sumatera Utara juga mengatakan bahwwa kendala utama yang dihadapi oleh BNN Sumatera Utara sendiri ialah lambannya koordinasi yang dilakukan dengan BNN RI. Seperti diketahui sebelumnya bahwa untuk mendapatkan data mutasi bank dan melakukan pemblokiran rekening bank, BNNP harus terlebih dahulu mengajukan surat permohonan permintaan data mutasi bank dan surat permohonan permintaan pemblokiran atas nama tersangka beserta dengan Laporan Pengajuan Perkara yang berisi resume berkas perkara $\underset{w w}{W}$ http://mahesainstitute.web.id/ojs2/index.php/jehss wmahesainstitut@gmail.com 
kepada BNN RI. Mengingat pentingnya data mutasi bank sebagai barang bukti utama, maka sangat diperlukan adanya kecepatan dalam melakukan koordinasi karena dikhawatirkan uang pelaku dapat beralih dan berpindah tangan sehingga penyidik akan kesulitan dalam melacak uang tersebut terlebih lagi jika terhadap rekening bank milik pelaku belum dilakukan pemblokiran maka tidak akan menutup kemungkinan semua sisa saldo tabungan akan diambil.

\section{SIMPULAN}

Kebijakan kriminal tindak pidana korporasi bagi perusahaan yang terlibat dalam pencucian uang hasil penjualan narkotika adalah dengan adanya Undang-Undang No 31 Tahun 1999 Jo. Undang-Undang Nomor 20 Tahun 2001 yang menggantikan undang-undang Nomor 31 Tahun 199 tentang Pemberantasan tindak pidana korupsi terdapat ketentuan baru yang sebelumnya tidak diatur dalam undang-undang yang sebelumnya, antara lain bahwa subjek tindak pidana berupa korporasi sebagaimana diatur dalam pasal 20 ayat (1). Bahwa hambatan dan solusi yang dilakukan oleh BNN Sumatera Utara dalam penanganan kasus tindak pidana korporasi bagi perusahaan yang terlibat dalam pencucian uang hasil penjualan narkotika adalah sulitnya mendapatkan informasi terkait dengan penelusuran mengenai harta yang menjadi objek hasil tindak pidana pencucian uang. Penanganan kasus TPPU, dimana BNN Sumatera Utara bekerja sama dengan PPATK, yang solusinya adalah berkordinasi dengan pihak PPATK, Hambatan lain adalah terkait dengan penyitaan aset tersangka yang harus bekerja sama dengan pihak bank, ketersediaan sarana dan prasarana yang kurang memadai.

\section{DAFTAR PUSTAKA}

Abidin, A.Z. (1983), Bunga Rampai Hukum Pidana, Jakarta : Pradnya Paramita.

Arief, B.N. (1995), "Bahan Penataran Hukum Pidana dan Kriminologi", dalam International Meeting Of Expert On The Use Of Criminal Sanction In the Protections Of Environment, Internationally, Domestically and Regionally, Portland, Oregon, USA, 19- 23 March 1994,.

Arief, B.N. (2003), "Tindak Pidana Pencucian Uang Dan Tindak Pidana Lainnya Yang Terkait", dalam Jurnal Hukum Bisnis, Volume 22, Nomor 3, Tahun 2003, Jakarta: Yayasan Pengembangan Hukum Bisnis.

Arifin, R., \& Choirinnisa, S. (2019). Pertanggungjawaban Korporasi dalam Tindak Pidana Pencucian Uang dalam Prinsip Hukum Pidana Indonesia (Corporate Responsibility on Money Laundering Crimes on Indonesian Criminal Law Principle). JURNAL MERCATORIA, 12(1), 43-53

Clinard, M.B. and Yeager, P.C., (1980), Corporate Crime, New York: The Free Press.

Coffe, J.C. (1998). Corporate Criminal Liability, dalam Barda Nawawi Arief, 1998, Dalam Sari Kuliah Perbandingan Hukum Pidana, Jakarta: PT. Raja Grafindo Persada.

Guraba, S., Dahlan, D., \& Rahayu, S. (2018). Penerapan Prinsip Perbarengan Tindak Pidana Narkotika dan Tindak Pidana Pencucian Uang di Pengadilan Tinggi Aceh. JURNAL MERCATORIA, 11(2), 204-211. doi:https://doi.org/10.31289/mercatoria.v11i2.1829

Husein, Y, (2004). Hubungan Antara Kejahatan Peredaran Gelap Narkoba Dan Tindak Pidana Pencucian Uang, Makalah, Diselenggarakan Oleh Forthy-Seventh Session of The Comisión on Narcotic Drugs, Wina, 2004.

Khairul, Mahmul S., dan Marlina, (2011), Kewenangan PPATK dalam Pencegahan dan Pemberantasan Tindak Pidana Pencucian Uang, Mercatoria, 4 (1): 33-42

Kistiani, Y, (2015), Pemberantasan Tindak Pidana Pencucian Uang Perspektif Hukum Progresif, Yogyakarta: Thafa Media.

Mertokusumo, S, (1999), Mengenal Hukum Suatu Pengantar, Yogyakarta : Liberty.

Michael Levi, Peter Reuter, 2006, Money Laundering, Chicago: The University of Chicago Press.

Muladi dan Priyatno, D, (2010), Pertanggungjawaban Pidana Korporasi, Jakarta: Kencana Prenada Media Group.

Muller, W.H., Kalin, C.H. \& Goldsworth, J.G. (eds). (2007). Anti-Money Laundering: International Law and Practice, West Sussex, England: John Wiley \& Sons Ltd and Henley and Partner.

Nasution, E. (2017). Pertanggungjawaban Pidana Korporasi Dalam Tindak Pidana Pencucian Uang. JURNAL MERCATORIA, 8(2), 132-144. doi:https://doi.org/10.31289/mercatoria.v8i2.652

Nugroho, N. (2017). Analisis Terhadap Pencegahan Tindak Pidana Pencucian Uang Oleh Bank BNI Ditinjau dari Undang Undang Nomor 8 Tahun 2010 Tentang TPPU. JURNAL MERCATORIA, 9(2), 119-135. doi:https://doi.org/10.31289/mercatoria.v9i2.435 
Prasetyo, R.T, Ma'ruf, U, \& Mashdurohatun, A, (2017). “ Tindak Pidana Korporasi Dalam Perspektif Kebijakan Formulasi Hukum Pidana”, dalam Khaira Ummah, Jurnal Hukum, Volume 12,Nomor 4 Desember 2017, Fakultas Hukum Universitas Islam Sultan Agung, Semarang.

Purwoko, S.W. (2001), Money Laundering, Praktek Dan Pemberantasannya, BEI NEWS Edisi 7 Tahun II, Oktober-Desember 2001.

Soekanto, S, (2014), Pengantar Penelitian Hukum, Jakarta: UI-Pres

Soekanto, S, (2014), Faktor-Faktor Yang mempengaruhi Penegakan Hukum, Jakarta: Rajawali Press.

Sundari, (2014). “Tindak Pidana Narkotika dan Pencucian Uang”, dalam Komisi Yudisial Republik Indonesia, "Pelatihan Hukum Pidana Khusus Bagi Hakim Tinggi. Proceeding. Medan 12-14 September 2014 di Medan.

Surbakti, E, (2016). "Strategi Badan Narkotika Nasional Daerah (BNND) Dalam Mengungkap Tindak Pidana Pencucian Uang Atas Kejahatan Narkotika". Makalah. Yogyakarta: Fakultas Hukum Universitas Atmajaya.

Tambunan, M.P. (2016). "Pertanggungjawaban Pidana Korporasi Dalam Tindak Pidana Pencucian Uang", dalam Mimbar Keadilan, Jurnal Ilmu Hukum, Januar-Juni 2016.

Wiretno, G.A. (2014), "Penelusuran Harta Kekayaan Tindak Pidana Pencucian Uang (Studi di Kantor Badan Narkotika Nasional Provinsi Jawa Timur)”. Makalah. Malang: Fakultas Hukum Universitas Brawijaya. 